whether he will not think it an intrusion: doubts which any editor who did wish for communications might dispel by making such an announcement as I have suggested.

R. R.

Lincoln's Inn.

NOTES UPON CUNNINGHAM'S HAND-BOOK OF LONDON.

St. Giles's Pound. - The exact site of this Pound, which occupied a space of thirty feet, was the broad space where St. Giles's High Street, 'Tottenham Court Road, and Oxford Street meet. The vicinity of this spot was proverbial for its profligacy; thus in an old song:-

"At Newgate steps Jack Chance was found, And bred up near St. Giles's Pound."

Dudley Court, St. Giles's. - This spot was once the residence of Alice Duchess of Dudley, in the reign of Charles the Second; and afterwards of the celebrated Lord Wharton. The mansion and gurdens were of considerable extent.

St. Giles's Hospital. - The celebrated Dr. Andrew Boorde rented for many years the Master's house. He is mentioned as its occupant in the deed of transfer between Lord Lisle to Sir Wymonde Carewe, dated in the last year of Henry the Eighth's reign.

Gray's Inn Lane. - Anciently called Portpoole. See the commission granted to the Master of the Hospital of St. Giles's, \&c. to levy tolls upon all cattle, merchandize, \&c., dated 1346, in Rymer's Fcedera.

Greut Queen Street, Lincoln's Inn. - Lord Herbert of Cherbury was one of the first inhabitants of this street, residing at the south side, near the east corner of Wild (or more properly Weld) Sireet, where he died in 1648 . The house is still standing, and is one of fifteen built in the third year of James the First. Powlet and Conway houses, also still standing, are among the said number. The celebrated Dr. Mead (d. 1754) resided in this street.

Turnstile Lane, Holborn. - Richard Pendrell, the preserver of Charles the Second, resided here in 1668. It is supposed that Pendrell, after the Restoration, followed the king to town, and settled in the parish of St. Giles, as being near the court. Certain it is that one of Pendrell's name occurs in 1702 as overseer, which leads to the conclusion that Richard's descendants continued in the same locality for many years. A great-granddaughter of this Richard was living in 1818 in the neighbourhood of Covent Garden. Richard Pendrell died in 1674 , and had a monument erected to his memory on the south-east side of the old church of St. Giles. The raising of the churchyard, subsequently, had so far buried the monument as to render it necessary to form a new one to preserve the nemory of this celebrated man. The black marble slab of the old tomb at present forms the base of the new one.

Eoward H. Rimbault.

Mrs. Cornelly's is stated, in vol. ii. p. 753., to be "the corner of Sutton Street," Soho Square, "now D'Almaine's." Mrs. Cornelly's was at the corner of Sutton Street, but has long been pulled down: the Catholic chapel in Sutton Street was Mrs. Cornelly's concert, ball, and masqueraderoom; and the arched entrance below the chapel, and now a wheelwright's, was the entrance for "chairs." D'Almaine's is two doors north of Sutton Street, and was built by Earl (?) Tilney, the builder of Wanstead House? The House in Soho Square has a very fine banqueting-room, the ceiling said to have been painted by Angelica Kauffinann. Tilney was fond of giving magnificent dinners, and here was always to be found "the flesh of beeves, with Turkie and other small Larks!"

Cock Lane. - The house in Cock Lane famous for its "Ghost" is still standing, and the back room, where "scratching Fanny" lay surrounded by princes and peers, is converted into a gas meter manufactory.

Naso.

\section{FOLK LORE.}

Easter Eggs. - The custom of presenting eggs at Easter is too well known to need description; but perhaps few are aware that, like many other customs of the early Church, it had its origin in paganism.

Sir R. K. Porter (Travels, vol. i. p. 316.) mentions that at a period of the year corresponding to Easter, "the Feast of nooroose, or of the waters," is held, and seems to have had its origin prior to Mahometanism. It lasts for six days, and is supposed to be kept in commemoration of the Creation and the Deluge - events constantly synchronised and confounded in pagan cosmogonies. At this ferst eggs are presented to friends, in obvious allusion to the Mundane egg, for which Ormuzd and Ahriman were to contend till the consummation of all things.

When the many identities which existed between Druidism and Magianism are considered, we ean hardly doubt that this Persian commemoration of the Creation originated our Easter eggs. G.J.

Buns. - It has been suggested by Bryant, though, I believe, not noticed by any writer on popular customs, that the Good Friday cakes, called Buns, may have originated in the cakes used in idolatrous worship, and impressed with the figure of an $o x$, whence they were called Bowv. The cow or bull was likewise, as Coleridge (Lit. Rem. vol, ii. p. 252.) has justly remarked, the 